\title{
Anti-Corruption Crusade in Nigeria: An Assessment of the Disposition of the National Assembly (1999-2013)
}

\author{
Vincent Nyewusira, Ph.D \\ Kenneth Nweke, Ph.D \\ Department of Political Science, \\ Ignatius Ajuru University of Education, \\ Rumuolumeni-Port Harcourt, Nigeria
}

Doi: $10.2478 / \mathrm{mjss}-2018-0090$

\begin{abstract}
Corruption has inadvertently been elevated to a state or national policy with all the symptoms of a hemorrhaging system. While any aggressive and purposeful anti-corruption crusade will always generate popular support and acclaim in Nigeria, it is sure to provoke anger, frustration and resistance among the political class with vested interest in the status quo. Periodically, the National Assembly, whose members largely belong to the latter group, is one of the institutions vested with the constitutional responsibility of preventing and exposing corruption, inefficiency and waste in the management of public funds within its legislative competence. This is specifically stipulated in section 88 (2) (b) of the 1999 Constitution (as amended). The study adopts the institutional approach to interrogate the efforts, capacity and political will of the National Assembly to function as the watchdog of public funds via legislations, inquiries or investigations, oversights, appropriations and resolutions. Our treatise includes a general survey and analysis of the Acts passed by the National Assembly establishing anti-corruption agencies such as the Independent Corrupt Practices and other related offences Commission (ICPC) and the Economic and Financial Crimes Commission (EFCC). We shall also do an exposition of some highprofile investigations conducted by the National Assembly over some federal government agencies pursuant to sections 88 and 89 of the constitution. Unfortunately, controversies and revelations arising from these exercises gravitated, in some cases, to narratives of sleaze in the National Assembly. It is also argued that the opaque and jumbo salaries and allowances associated with members of the National legislature significantly detract from any anti-corruption posturing of that institution. We conclude that mere sloganeering and platitudes on the powers of the National Assembly in combating corruption will yield little or no results until operators of the legislative arm of government at the national level understand and perform their critical role as the 'soul and conscience of good governance'.
\end{abstract}

Keywords: corruption, anti-corruption crusade, legislature, good governance.

\section{Introduction}

Corruption is a global phenomenon that is common in all societies. However, the degree of occurrence differs from one society to another. That is why it is often said that 'corruption is a problem in Nigeria, but not exclusively a Nigerian problem'. According to the corruption Perception Index of Transparency International, Nigeria is ranked as one of the most corrupt countries in the world. Precisely, between 1999 and 2003, Nigeria occupied either the $1^{\text {st }}$ or $2^{\text {nd }}$ position in Transparency International's survey of the most corrupt countries of the world (Bello-Imam \& Obadan, 2004:2, Ogham-Emka, 2005:14, Emweramadu, 2010:6). Again, economic indicators show that by 1999 , before the advent of democratic dispensation, the level of corruption in Nigeria 
reached a feverish pitch (Ogbolu, 2006:119).

Most development scholars have identified corruption as the biggest obstacle to economic and social development, and a phenomenon that undermines democracy and rule of law. Mogholu (2009:27) states the impact of corruption in the entire African region as follows;

Corruption has been at the core of public sector governance and business since the post-colonial modern African State, preventing the very take-off of serious national development. In some African countries, what passes for 'government' or 'governance' is really a vast institutionalized and criminal enterprise of bribery, stealing and sharing public funds, and private sector businesses are built and sustained by their complicity in the scheme and other forms of sharp practices.

Nwosu (2011:18) shares the sentiments of Moghalu when he noted that the level of corruption in Nigeria 'attacks the foundations of democratic institutions by distorting electoral process, preventing rule of law, and creating bureaucratic quagmires'. Both scholars recognize corruption as a grave national problem that undermines democratic governance and retards economic development. It is in the same vein that former President Olusegun Obasanjo, in his inaugural address on May 29, 1999 noted that 'corruption is the greatest single bane of our country today', and that 'no society can achieve anything near its full potential if it allows corruption to become the full-blown cancer that it has become in Nigeria. Ribadu (2005:42) also admits that Nigeria's perennial problems of instability, underdevelopment, lawlessness and poverty are direct consequences of the dominant status of corruption in the polity. In fact, Nobel Laurete, Wole Soyinka, once declared that corruption is 'Nigeria's nightmare'. Nothing can be truer than these observations. It is instructive to note that the Corrupt Practices and other Related Offences Bill, which seeks to prohibit corrupt practices and prescribe appropriate punishment for such, was the first executive bill forwarded by the Obasanjo administration in 1999 to National Assembly. The bill was passed into law by the National assembly as 'The Corrupt Practices and other Related Offences Act, 2000'.

The Constitutional architecture of Nigeria designates the National Assembly as 'the watchdog of public funds' in Sections 99 and 89 of the 1999 constitution (as amended). While Section 88(2) (b) empowers the National Assembly to 'expose corruption, inefficiency or waste in the execution or administration of laws within its legislative competence...,' Section 89 grants the National Assembly enormous powers to summon, examine and investigate any person in Nigeria and cause evidence to be procured in the course of performing its legislative functions. The combined effects of Section 88 and 89 , no doubt, is intended to make the National assembly the bastion of anti-corruption crusade, driver of corrupt-free state, and guardian of public funds. The 'watchdog' function of the National Assembly, according to Ogbondah (2004:378), involves 'investigating and unearthing the quantum levels of corruption, bribery, embezzlement, ineptitude, lack of accountability, graft and other nefarious practices inherent within the factions and fractions of the ruling civilian bourgeoisie'.

Section 4 of the constitution also stipulates that 'the National Assembly shall have power to make laws for the peace, order and good government of the Federation or any part thereof'. Good government, according to McCauley (2011:18), remains the cornerstone for any nation's political and economic development. This critical role of the National Assembly probably explains why John Locke describes the legislature as 'the supreme powers of the commonwealth'. A major component of legislating for 'good government' as prescribed in Section 4 is combating all forms of corruption in public sector management (Idebisi, 2013).

The focus of this paper is on economic and financial corruption, which many believe is systemic, and the disposition of National Assembly in combating it. The stranglehold of this type of corruption on Nigeria's body polity has made the fight against it develop into an important public policy issue since the return to civil rule in 1999. Economic and financial corruption in public sector results in re-directing resources from intended public use like education, health, works, etc. to illegitimate private benefit. In the process, corrupt public officials cause massive human deprivation gravely affecting the livelihoods of the poor, weak and vulnerable members of the society. It basically impedes government efforts to deliver services to citizens (Nyewusira, 2007:30). As a matter of fact, Nwosu (2011:8) considers this aspect of corruption as the mono-causal factor to the collapse of both the First and Second Republics in Nigeria. Therefore, people are concerned about 
what the National Assembly does or fail to do since the role of the legislature is central to the democratic development of any country. It is against this background that the study examines the extent to which the conducts and activities of members of the National Assembly promote or impede anti-corruption policies in Nigeria.

\section{Theoretical Perspective}

The legislature is an institutional body responsible for making laws for a nation and one through which the collective will of the people or part of it articulated and expressed. (Nyewusira \& Nweke, 2013). To examine the disposition of the National Assembly in the anti-corruption crusade in Nigeria, we relied on institutional Approach. Dyke (1967) in Enemuo (2005:20) defines an institution as 'any persistent system of activities, or any pattern of group behaviour', and as 'offices and agencies arranged in a hierarchy, each agency having certain functions and powers'.

Institutional Approach is 'one of the classical approaches attributed to the works of early political thinkers such as Plato, Aristotle, Hobbes, Locke, Rousseau, Montesquieu, etc., who studied political phenomena in ancient times. Other notable traditional or classical approaches are philosophical, historical and legal approaches (Paki \& Inokoba, 2006:27) these classical political thinkers concentrated their studies on political institutions such as the legislature, executive and judiciary, which performed functions of rule making, rule enforcement and rule interpretation, respectively. Institutional Approach was dominant in early political studies and is still adopted by modern scholars to study governmental or political institutions, such as the legislatures, executives (bureaucracies), judiciary (courts) and political parties. The emphasis is on both their formal or structural aspects vis-à-vis their processes. The approach is both descriptive and analytical of the operations of these institutions. As a matter of fact, the legislature is one of the agencies of government that the institutional approach usually classifies and describes.

Institutional approach examines functional aspects of political structures and focuses on the various governmental institutions, describing their structures, organization, duties and expected functions. As Dyke (1967:9) noted, the choice of institutional approach 'follows quite understandably from widely accepted view that the study of politics is the study of the state of governmental and related institutions'. Accordingly, the institutional approach to political inquiry focuses on the formal structures and agencies of government. Institutional analysis by Dyke (1969) and Ezeani (2010) reveals the influence of political institutions on individual behaviour or decisions. Thus, a high proportion of actions or decisions that people take are done on the basis of institutional conditioning.

By this approach, it is assumed that an understanding of the operations and transactions of the Legislature, in this case the National Assembly, is critical to either achieving or undermining good governance. This is because any policy not supported by the legislature is not likely to be sustainable since the legislature is at the very heart of any democratic system or what is often referred to as 'representative governance'. In fact, Ayodele (2004:65) is of the view that more than any other institution, the legislature is 'a core determinant of the character of the state'. As Ogunbiyi (2011:34) also noted, 'the state or level development of any country is strongly determined by capability of the legislature'. Thus, the widely held view that the legislature can leverage on its enormous powers to galvanize national development by enacting development-centred laws and carrying out meaningful oversight functions on other arms of government. It is in this respect that the study adopts Institutional Approach to ascertain the extent to which the National Assembly pursued good public policies for national development, especially in the anti-corruption crusade.

A major criticism of Institutional Approach is that it is merely descriptive in orientation. In spite of this weakness, the study used the approach to analyse the constitutional and legal powers of the National Assembly, their challenges, actions, accomplishments and failures in the anti-corruption crusade. From the study, valuable insights on the organization of the National Assembly were drawn, reforms proposed and general conclusion offered. 


\section{Evolution and Structure of the National Assembly}

Nigeria stated self-governing with Parliamentary system of government in 1960. The system could not, however, be sustained because of the disruption and turmoil caused to the political process by the unfortunate military coup of January 15, 1966. On return to civil rule in 1979, the dominant constitutive element of the Nigerian state, comprising the military and the political class, opted for the American Presidential system. The presidential system of government depends on the strict adherence to separation of power among the three arms of government: the legislature, executive and judiciary. The legislature is generally seen as one of the basic structure of any political system. It is known by variety of names in different countries. In Nigeria, the legislature at the federal level is known as the National Assembly. The National Assembly was first established in the 1979 Constitution and replicated in subsequent 1987 and 1999 Constitutions.

The 1999 Constitution (as amended) established the institution of the National Assembly in Section 4(1). It reads:

The legislative powers of the Federal Republic of Nigeria is shall be vested in National Assembly for the Federation which shall consist of a Senate and a House of Representatives.:

Section 4(2) encapsulates the powers' of the National Assembly to act as the harbinger of good governance. In the words of the constitution, 'the National Assembly shall have power to make laws for the peace, order and good government of the Federation or any part thereof: ...... '. This provision underscores the fact that the National Assembly ought to be a critical anti-corruption institution since 'good government' is a farce in a corrupt political system.

The National Assembly is a bicameral legislature; Senate with 109 members and a 360member House of Representatives. The body is supposed to guarantee equal representation of the 36 states irrespective of size in the Senate and proportional representation of population in the House (Sections 48 and 49, 1999 Constitution). The National Assembly, like many other organs of the Nigerian government, is based in the Federal Capital Territory, Abuja. The Senate and the House of Representatives is led by the President of the Senate and Speaker of the House of Representatives respectively. At any Joint Session of the National Assembly, the President of the Senate presides and in his absence the Speaker of the House of Representatives presides. Both chambers of the National Assembly are empowered, in Section 60 of the Constitution, to regulate their procedure. The National Assembly stands on tripod responsibilities of representation, law making and oversight.

\section{Powers and Control of the National Assembly over Public Funds}

In the context of protecting public funds, the functions of the National Assembly revolves, mainly, around the following:

a. Scrutiny and Approval of Annual Budget/Estimates

b. Authorization of expenditure from Consolidated Revenue Funds

c. Auditing of Public Accounts

d. The conduct of investigations to expose corruption, inefficiency and waste.

A consideration of these issues serves to highlight the role of National Assembly, primarily as a watchdog of public funds, and ultimately as anti-corruption crusader.

a. Scrutiny and Approval of Annual Budgets /Estimates:- Budget is the instrument for deployment or allocation of financial resources to various sectors within the relevant fiscal year. The constitution provides that Appropriation Bill must be considered and approved by the National Assembly in each financial year before money can be withdrawn from the appropriate funds for running of government. The consideration and passing into law of the Appropriation Bill is the important measure by which the National Assembly becomes the watchdog of Public Funds. The process enables the National Assembly ascertain the revenues of government and how those revenues are to be expended. In fact, the constitutional treatment of matters relating to appropriate bill illustrates the emphasis 
placed on the need for the input of the National Assembly in the control of Public Funds. It is such that the President and other members of the Executive Council of the Federation cannot spend any public fund, for any reason(s), until and unless it has been presented as an appropriation Bill and approved by National Assembly. Therefore, 'the power to spend or not to spend' public fund belongs to 'the National Assembly. As Tribe (1988) in Guobadia (1999:75) affirms, 'the power of the purse belongs to Congress'.

b. Authorization of Expenditure from the Consolidated Revenue Fund and other Public Fund: Section 80(1) of the constitution provides for the establishment of consolidated Revenue Fund wherein all revenues received by the Federation are paid into. Section $80(2)(3)(4)$ require that only the National Assembly can authorize withdrawal of money from Consolidated Revenue Fund or any other Public Fund of the Federation by an Appropriation Act or Supplementary Appropriation Act. The withdrawals must also be done in the manner prescribed by National Assembly. The implication of Section 80 is that the Public Funds kept in 'Consolidated Revenue Fund' and 'any Public Fund of the Federation' can only be withdrawn when authorized by an Act of National Assembly. In other words, the administrative powers usually given to the Executive (power of spending) must be subject to the provisions of the Act of National Assembly that such money be spent. The measure of control which the National Assembly has over the Executive in matters relating to expenditure of public funds is extensive. The essence, according to Guobedia (1999:77) is to guard against 'expenditure without authorization'.

Another Public Fund which comes under the control of National Assembly is the Contingencies Fund. The National Assembly may, by law, make provisions for establishment of Contingencies Fund for the Federation. This is stipulated in Section 83 of the Constitution. The purpose of this Fund is to enable the President carryout an urgent and unforeseen expenditure which may arise and which no provision was earlier made by the Appropriation Act. The President cannot make any expenditure in the Fund except with the approval of National Assembly. The National Assembly must be satisfied that the expenditure is as a result of 'urgent and unforeseen need' before it approves. This provision leaves much to the discretion of National Assembly- as to when there has arisen 'an urgent and unforeseen needs' for such expenditure.

c. Auditing of Public Funds: One vital aspect of National Assembly's role as a watchdog of public funds is in area of auditing of public expenditure. It is one notable medium of post appropriate control of public funds by National Assembly. In this context, Section 85 (2) (5) prescribe that the Auditor-General for the Federation submits audited public accounts of the federation and of all offices and courts of the federation to each House of the National Assembly for consideration by the Public Accounts Committee of both Chambers. By these provisions, the National Assembly is in a position to check on the legality of expenditure of Public Funds and determine whether such funds could have been better employed. Thus, not only does the National Assembly conduct a finance and regularity audit that is to ensure that expenditure was made for the purposes authorized in the Appropriation Act, it also carries out what Guobadia (1999:82) refers to as 'a value for money audit'. This enables the National Assembly examine the effectiveness and efficiency to which public funds have been applied by various Ministries, Departments and Agencies of government.

d. The Conduct of investigations to expose corruption, inefficiency and waste: A corollary to auditing of public funds is the constitutional power vested in National Assembly to direct or initiate investigations into 'the conduct or affairs of any person, authority, ministry or government Department charged, or intended to be charged, with the duty or responsibility for' spending public funds and executing laws enacted by National Assembly. The investigatory functions of National Assembly, with a view to acting as watchdog of public funds, are prescribed in Sections 88 and 89 of the constitution. The purpose of the inquiry or investigation, in the letter of the constitution is to, 'expose corruption, inefficiency or waste in the execution or administration of laws within its legislative competence and in the disbursement or administration of funds appropriated by it'. Under these provisions, 
the National Assembly can procure whatever evidence it requires; summon any person to give evidence and produce any document or other things in his possession or control and to examine such a person. The National Assembly can also compel the attendance of any person so summoned by warrant. Investigations by National Assembly serves as a potent source of control over public funds, and can make all persons or institutions who manage public funds realize that their conducts and operations could be a subject of legislative scrutiny at any time. The constitution, therefore, empowers the National Assembly to surprise Ministries, Departments and Agencies. This supervisory function of National Assembly is performed through what is known in legislature parlance as 'oversight function. It is mostly undertaken or carried out by standing committees of both chambers. The forgoing is a general analysis of the provisions of the constitution dealing with the powers and control of the National Assembly over public funds. Hence, the constitution has very clearly made the National Assembly to be the watchdog of public funds and an anti-corruption institution.

\section{Appraising National Assembly as Watchdog of Public Funds Vis-à-Vis Its Anti-Corruption Disposition}

At the height of the global financial crisis between 2010 and 2012, economic analysts with some social conscience resented unconscionable wages of public officials and chief Executive Officers (CEOs) of private organizations. Even in a system of free enterprise, people were conscious of the systemic implications about excessive remuneration of private businessmen and the ruinous social consequences. Consequently, public officers in most developed countries had to cut their wages in response to difficult economic situations. It was a form of wage regulation by sheer force of example and concern about the widening social inequality. The response and situation were, however, different in Nigeria's National Assembly as legislators, in the words of Komolafe (2010:64), 'increased their emoluments in a most provocative manner'.

On August, 8, 2010, Thisday Newspapers reported that in 2009, members of National Assembly 'received a total of N102.8 billion comprising N11.8 billion as salaries and N90.6 billion as non-taxable allowances'. Komolafe describes the payment of this whopping sum to 469 persons in an economy in which workers go on strike to demand N18,000 monthly minimum wage as a 'huge drain on the public treasury'. In the same publication of Thisday Newspaper, Professor Itse Sagay, a Constitutional Lawyer and Scholar, was reported to have said that 'a Senator earns N240 million (\$1.7 million) in salaries and allowances while his House of Representative counterpart earn about (204 million (\$1.45 million) per annum’. Itse Sagay compared the earnings of National Assembly members with the American Senator who earns \$174,000 and United Kingdom Parliamentarian who earns about $\$ 64,000$ per annum. These figures are very low compared with that of Nigerian legislators. Itse concludes that National Assembly members are the highest paid legislators in the world. On her part, Ikokwu (2011:18) writes that between 2007 and 2011, a senator in Nigeria earned N15.8 million per month, while a member of House of Representatives earned N10.59 million monthly in salaries and allowances. She compared it to a United States of America Senator who earns only N2.17 million monthly, and a British Member of Parliament's monthly salary of N0.8 million. Ikokwu further noted that in Australia, a legislator's monthly pay is equivalent to N175,000. She concluded that in spite of public outrage, members of the National Assembly increased their annual budget from N111 billion in 2010 to N232 billion in 2011. As it stands today, too many figures are bandied round with regular frequency on the salaries and allowances received by members of National Assembly. The figures are speculated to be N28 million quarterly for each member of House of Representatives and N36 million quarterly for each Senator (Nwogwugwu, 2011:72). In 2012, the former Governor of Central Bank of Nigeria (CBN) Mallam Sanusi Lamidu Sanusi, revealed that the National Assembly receives $25 \%$ of the National recurrent budget. Despite the furor generated by this revelation, no rebuttal of the allegations or by way of explanation or clarification came from the National Assembly. According to Itse Sagay, 'the salaries and allowances of members of National Assembly represent a cruel anomaly in the country's democratic governance'. Komolafe (2010:64), on his part, sums up the earnings of members of 
National Assembly in a socio-economic environment, defined by pervasive poverty, as 'economically illogical, social insensitive and morally repugnant'. In the same vein, Aboyade (2010:111) observed that members of National Assembly 'add no value to the economy but rather constitute a drain on it'. Whether the figures presented by Itse Sagay, Ikokwu, Nwogwugwu and Sanusi are true or not, the subject of the salaries and allowances of National Assembly Members is shrouded in secrecy with an opaque veil put on it. As Nwogwugwu (2011:72) affirms, not even the Revenue Mobilization Allocation and Fiscal Commission that is statutorily bound to determine the salaries, allowances and fringe benefits of members of National Assembly appears to be certain as to how much the legislators pay themselves.

It is not generally known that beyond the surface of criticisms associated with the earnings of members of the National Assembly, there are deeper questions about the body language of the National Assembly to fight corruption. To start with, the National Assembly, as critical institution of democracy, has rarely addressed the structural foundations of corruption that is inherently bolstered by the 'Nigerian factor', which is a metaphor for official corruption and institutional failure. For instance, how many members of National Assembly can honesty account for their acquisition within the system? Nigerians are witnesses to huge investments, luxury houses, state of art automobiles and grandiose properties acquired by members of National Assembly across Nigeria and overseas. The truth is that most legislators do not own up to the logic of primitive accumulation which governs both Chambers of the National Assembly. The character of the National Assembly, as an institution, shows that it cannot address the fundamentals of corruption or be insulated from the vagaries of contemporary corrupt political economy. Kunle (2010:16), for example, accused the National Assembly of 'watering down' the Independent Corrupt Practices and Other Related Offences Commission (ICPC) and the Economic and Financial Crimes Commission (EFCC) bills sent to it by former President Obasanjo. Similarly, the original and stringent provisions of Freedom of Information Bill were tinkered with by the National Assembly and reluctantly passed after about five years. Little wonder Aboyade (2010:10) described members of National Assembly as 'vampire elites, due to their proclivity for corrupt practices. An account of some cases of corruption and financial scandals associated with National Assembly will suffice.

Since the return to civil rule in 1999, the National Assembly has lurched from one scandal to another associated with financial malfeasance, corruption and outright embezzlement of public funds. Ishiekwere (2005) captures it as 'prevailing corpus of nauseating events in the National Assembly'. The leadership of the Senate was enmeshed in allegations of squandering N16 million on Christmas gifts and hampers in December 2000. The scandals involved the Senate President, late Chuba Okadigbo, and the Deputy Senate President, late Haruna Abubakar. This led to the ouster of the duo in 2001 following a motion moved by Senator Waheb Dosunmu for their removal. It marked the beginning of highly popularized 'Banana peels' inside the Chambers of the National Assembly that is said to be responsible for the fall of members with corrupt tendencies. It was the period members of National Assembly were also accused of receiving N5 million each for furniture allowance. In 2002, the Senate under the leadership of Ayim Pius Ayim, moved to review the Independent Corrupt Practices Act, when some members of the Senate were allegedly accused of infractions against the Act. The development provoked condemnation from civil society organizations who described the move by the Senate to scrap the Commission as 'a show of legislative recklessness' (Ogunmade, 2007:18). The action of the National Assembly was necessitated by the Commission's attempt to bring some members of the National Assembly, who violated the tenets of the Act setting it up, to book. This suggests that the National Assembly does not really believe in the anti-corruption mandate of ICPC which it enacted.

The integrity of the Second National Assembly, inaugurated in June 2003, was severely dented at inception when the former Minister of Federal Capital Territory (FCT), Mallam Nasir elRufai, came up with an allegation that the Deputy Senate President, Ibrahim Mantu, demanded millions of naira from him, on behalf of the Senate, during the ministerial screening exercise in 2003. The bribe allegedly demanded was to ensure easy confirmation of el-Rufai as a Minister by the Senate. Although the Senate Committee on Ethics and Privileges eventually cleared Senator Mantu of any wrong doing, (on the ground that el-Rufai's allegation could not be substantiated) the entire Senate never overcame the image crisis that the allegation of extortion and corruption 
brought the National Assembly throughout that tenure.

Another allegation of financial corruption associated with the Second National Assembly between 2003 and 2007 was the 'bribe-for-budget' scandal involving the Senate President, Adolphus Wabara, Chairmen of Senate Committees on Appropriation and Education (Senators John Mbata and Badamosi Maccido), Chairman House of Representative Committee on Education (Hon Shehu Matazu), Senators Chris Adigh-ije, Ibrahim Abdulaziz, Hon Osita Izunaso and officials of the Federal Ministry of Education. Preliminary investigations by Economic and Financial Crimes Commission (EFCC) revealed an extortion and blackmail of the Ministry of Education by these members of the National Assembly. Various sums of money ranging from N10 million to N5 million were alleged to have been paid by the Ministry to each of the legislators involved to facilitate approval of the Ministry's budget by the National Assembly. The incident led to a nation-wide broadcast by former President Obasanjo, where he castigated the Senate President and others involved in the bribery scandal and championed the removal of Wabara as Senate President. Again, the constitution amendment exercise undertaken between 2005 and 2006 had the image of the National Assembly smeared in perhaps, what could be termed the greatest allegation of bribery, corruption and inducement over 'third term' saga. It was widely speculated that members of National Assembly were induced with millions of naira and oil blocs to support Obasanjo's tenure elongation project. It was public knowledge that many pro-third term legislators were offered bribes to the tune of N50 million each to support the ill-fated third term agenda. The statements by some legislators such as Hon Sola Adeyeye and Hon. Wumi Bewaiji during and after the third term debacle gave credence to these allegations (Ogunmade, 2007:19).

The Third Session of the National Assembly, particularly the House of Representatives, was engulfed with the allegation of N628 million scandal against the Speaker of the House, Hon. Patricia Etteh and her Deputy Hon. Babangida Nguruje. It was alleged by Integrity Group, a pressure group in the House, that the leadership of the House awarded contracts to the tune of N628 million for renovation of their official residences. The intrigues and controversy generated by the allegation eventually culminated in the resignation of the Speaker and Deputy Speaker of the House. With the exit of Mrs. Patricia Etteh and Babangida Ngurorje, and the election of Hon. Dimeji Bankole and Hon. Usman Nafada as Speaker and Deputy Speaker respectively, the House of Representatives assumed a toga of what former Chairman of EFCC, Mrs. Farida Waziri, called a 'House of Scandals'. In her words, 'I think most Nigerians have been very concerned because there has been scandal upon scandal in that House, and that is the bastion of democracy and the hope of the common man' (Thisday Editorial, July 5, 2010:19). In fact, there was constant quibbling over money and contracts in the National Assembly to the extent that Ishiekwere $(2005: 11)$ wrote that 'Aburja is the nation's honey pot and the National Assembly exist to dispense the broth'. These comments are against the background of deluge of corruption, embezzlement, extortion, contract scams and misappropriation cases associated with the House of Representatives under the leadership of Hon. Dimerji Bankole. At a time, a member of the House, Hon. Dino Melaye, led a group of legislators that severally accused the leadership of the House under Dimeji Bankole of gross mismanagement of over N9 billion capital budgets of the House for 2008 and 2009, especially in the purchase of Peugeot cars for the various Standing Committees of the House. The controversy got to a climax when anti and pro-Bankole factions fiercely attacked each with weapons and engaged in 'boxing bout' on the floor of the House, and in the presence of secondary school students who has been admitted into the gallery to observe the plenary session. The sordid incident only confirms the statement of Anthony Goldman in London Economist of May $28^{\text {th }}-$ June $3^{\text {rd }}, 2011$ that 'Nigerian Politics is nothing but one big fight over oil money'.

The House of Representatives under the leadership of Dimerji Bankole was also embroiled in alleged financial misconduct of procuring a loan of N10 billion from a commercial bank. It was reported by a section of the media that members of the House of Debated the loan at an executive session (outside public view), even when it is clear that the legislative arm of government cannot procure loans and spend same outside the provisions of the Appropriation Act (Aboyade, 2010). Although some of these allegations against Dimeji Bankole and his Deputy, Usman Nafada, are presently subjects of litigation in court, the London Economist referred to above, unabashedly condemned the financial scandals involving the leadership of House of Representatives when it 
stated that 'the entire Nigerian State machinery exists to siphon funds'. For the constitutional watchdog of public funds to be facing intractable transparency crisis calls to question the legislative agenda of the National Assembly.

The allegations of financial impropriety bordering on criminality within the National Assembly are exacerbated by the conduct of some of its Standing and Ad-hoc committees. In the first place, the unwieldy number of Standing Committees in the National Assembly, 75 committees in the House of Representative and 43 in the Senate, are not only a huge drain on public funds, but the sheer gargantuan size reinforces the perception of profligacy in the court of public opinion. As Edomaruse $(2005: 48)$ observed, it is at the committee level that most of the reported corruption have taken place since 1999. The Ad-hoc Committee instituted by the leadership of House of Representatives to probe fuel subsidy regime in January 2012 turned out to be a case of 'the hunter being hunted' Mr. Femi Otedola, a major player in the Petroleum Downstream sector, publicly accused the Chairman of the probe Committee, Hon Farouk Lawan, of demanding and receiving bribe of $\$ 620,000$ from him in 'a sting operation'. It was a similar case with the House of Representatives Committee that investigated infractions and financial mismanagement in Nigerian Capital Market. The Director-General of Security and Exchange Commission (SEC), Ms. Arumeh Otah, during the public hearing accused the Chairman of Stock Market Committee, Hon. Hembe, of diverting huge estacode he received from the Commission without attending a proposed stock exchange conference in the United States of America. These matters are pending in various courts. The National Assembly probe of over $\$ 15$ billion purportedly injected into the Power Sector without visible output by the Obasanjo administration also left the credibility of National Assembly severely battered. Before the House could formally receive, adopt and debate report of the probe, the Chairmen of both Senate and House Committees on Power, Senator Nicholas Ugbare and Hon. Ndudi Elumelu, were arrested and arraigned in court by EFCC on charges of corruptly diverting millions of naira earmarked for National Independent Power Projects (NIPP). Other areas like constituency projects initiated and executed by legislators, sponsored foreign trips, exercising of oversight powers and budget defense by executive arm have equally been turned into avenues of corruption and application of public funds as slush funds by the National Assembly. In fact, Ministers, Departments and Agencies have consistently accused National Assembly of turning legislative oversight' to 'legislative extortion' leading to adversarial relationship between the executive arm of government and the national assembly (Komolafe, 2010).

Finally, between 1999 and 2013, three out of the five Speakers elected in the House of Representative were impeached and removed on allegations of corruption and unethical practices. One of the former Speakers that survived impeachment is facing prosecution on charges of corruption and embezzlement of public funds after his tenure. In the Senate, three out of six Senate Presidents were also removed from office on allegations of corruption and unethical conducts. An institution with such recurring decimal of corruption and extra-legal means of appropriating public funds cannot lay any claims to anti-corruption posture. We shall conclude this treatise by sharing a comic story that drives home public perception of National Assembly as a corrupt institution. According to the story, circulated in social media, a boy of about 12 years was caught stealing meat from his mother's pot of soup. The angry mother beat the boy and scolded him saying, 'if you don't stop stealing, do you know where you will end up?'. The boy answered, 'yes, I know'. The mother in a bemused state asked, 'where do you think you will end up?". The boy answered with confidence, 'I will end up in National Assembly'.

\section{Conclusion}

Although the National Assembly, by the provisions of the constitution is both the watchdog of public funds and anti-corruption institution of government, it is operated as a predatory institution. Anticorruption crusade can only be on the legislative agenda of National Assembly when the people control political power within the ambit of democratic governance. Potent anti-corruption policies cannot be contemplated or driven by National Assembly outside the framework of democratic governance which is almost elusive in Nigeria. Put differently, the National Assembly cannot be effective anti-corruption crusade until the most pernicious form of corruption, which is corrupt 
process of accessing power, is addressed. It is common knowledge that the road leading to power in Nigeria is laden with corruption, and that is why those who have a strong predilection for corruption appear to constitute the majority in National Assembly.

Expecting a National Assembly whose majority of members access political power through a dysfunctional and corrupt electoral process to fight any form of corruption is the height of mendacity. Therefore, the National Assembly can only key into anti-corruption crusade if and when Nigeria's electoral culture is built and sustained on the principles of constitutionalism, internal party democracy, responsive media, freedom of choice, impartial judiciary, progressivism and ideological politics. As a matter of fact, every democratic system presents the citizens with options for 'paradigm shift'. The process begins with registering to vote, voting and protecting the votes. There is no doubt that with active citizens' participation in this process, credible persons will be elected into the National Assembly, and the crusade to rebuild national infrastructure, alleviate poverty, revive the economy, and most importantly, curb corruption, will be directed from the 'hallowed' National Assembly.

\section{References}

Aboyade, F. (2010). Just what does this House stand for?. Thisday, November 9.

Ayodele, B. (2004). Institutional development and democratic consolidation in the Nigeria Fourth Republic. In K. Ajayi \& B. Ayodele (eds.) Perspectives on democracy and development in post-military Nigeria. Ibadan: Julius \& Julius Associates.

Bello-Iman, I.B. \& Obadan, M.I. (2004). Democratic governance and development management in Nigeria's Fourth Republic (1999-2003): the prologue. In I.B Bellow -Imam, \& M.T Obadan, (eds.) Democratic governance and development management in Nigeria's Fourth Republic (1999-2003). Ibadan: JODAD publishers.

Dyke, V.V. (1967). Political Science: a philosophical analysis. Standford: Standford University Press.

Enemuo, (2005). Approaches and methods to the study of politics. In R. Anifowose \& F. Enemuo (eds.) Elements of politics. Lagos: Sam Iroanusi publication.

Enweremadu, D.U. (2010). Anti-corruption policies in Nigeria under Obasanjo and Yar'adua: what to do after 2011?. Abuja: Fredrick Ebert Shifting. A discussion paper, No. 1. November.

Ezeani, E. (2010). Political science: an introduction. Abakaliki: Willy Rose \& Appleseed publishing coy.

Guobadia, A. (1999). The legislature as a watchdog of public funds. In I.A Umezulike (ed.) Towards the stability of the Third Republic. Enugu: Fourth Dimension Pub. Co. Ltd.

Idebisi, O. (2013). Dealing with corruption in Nigeria. The Punch, June 21.

Ikokwu, C. (2011). The imperative of a parliamentary watchdog. Thisday, July I.

Ishiekwere, A. (2005). The editor's perception of the House of Representatives. Thisday, December 17.

Komolafe, K. (2010). The lawmaking industry. Thisday, November 24.

Moghalu, K. (2009). Confronting corruption as a strategic risk. The Guardian, July 12.

McCulley, T. (2011). Governance: now comes the hard part. Thisday, June 27.

Nwogwugwu, I. (2011). The cost of governance (11). Thisday, June 27.

Nwosu, E. (2011). Harmonization of anti-corruption bodies. Thisday, July 19.

Nyewusira, V. (2007). Selected socio-political issues in Nigeria: religious institutions as agents of change. Journal of Pedagogy and Educational Development, 12 (1), 29-36.

Nyewusira, V. \& Nweke, K. (2013). The legislature and conflict management mechanism at the third tier level in Nigeria. Nigeria Journal of Social Sciences, 9 (2), 27-41.

Ogbondah, C.W. (2004). State-press relations in contemporary Nigeria. In I.B Bello-Imam, \& Obadan, M.I. (eds.) Democratic governance and development management in Nigeria's Fourth Republic (1999-2003). Ibadan: JODAD publishers.

Ogbolu, M. (2006, May-July). Tackling corruption from within. Lagos Organisation Review. 2 (4).

Ogham-Emeka, C. (2005). Chris Oyakhilome and the youth. Thisday, October 14.

Ogunbiyi, K. (2011). A divided legislature. Thisday, April 16.

Ogunmade, P. (2007). National Assembly: from one scandal to another. Thisday, September 10.

Paki, F. \& Inokoba, P. (2006). An invitation to Political Science. Port Harcourt: Kemuela Publishers.

Ribadu, N. (2005). Nigeria: why apathy to corruption is worrisome. Thisday, October 26. 